\title{
Penerapan Diversi Terhadap Anak Dalam Perkara Kecelakaan Lalu Lintas
}

\author{
Arsyad, Umar Hasan, Tri Imam Munandar
}

Fakultas Hukum, Universitas Jambi, Indonesia

\begin{abstract}
ABSTRAK
Tujuan yang dicapai dari penelitian untuk memberikan solusi terhadap kendala dalam penerapan Diversi. Hal tersebut berkaitan dengan tingginya kecelakaan lalu lintas yang pelakunya anak. Permasalahan dalam kecelakaan lalu lintas yang melibatkan anak sebagai pelaku yang dapat menyebabkan luka ringan, luka berat, bahkan korban meninggal dunia, memerlukan solusi yang terbaik dilakukan dalam penyelesaiannya adalah dengan Penerapan Diversi. Namun dalam penerapannya sebagai upaya mewujudkan Restorative Justice bisa memunculkan permasalahan dalam pelaksanaannya. Jenis penelitian ini merupakan penelitian normatif, dengan mengkaji bahan hukum primer maupun skunder. Hasil penelitian menunjukkan bahwa kasus kecelakaan lalu lintas yang melibatkan anak sebagai pelaku bisa diupayakan diversi dan wajib diupayakan dalam proses peradilan pidana anak sebagai upaya dari restorative justice, namun kendala yang dihadapi dalam Diversi yaitu tidak semua kasus kecelakaan lalu lintas yang dilakukan anak dapat dilakukan diversi karena tidak adanya kata sepakat antara pelaku dan korban. Hal tersebut terjadi karena kurangnya pengetahuan masyarakat tentang Diversi serta sulitnya untuk mencapai kata sepakat antara pelaku dan korban mengenai ganti kerugian karna belum diaturnya secara jelas mengenai ganti rugi dalam Undang-Undang Sistem Peradilan Pidana Anak.
\end{abstract}

Kata Kunci: Anak; Diversi, Kecelakaan Lalu Lintas

\section{PENDAHULUAN}

\section{Latar Belakang Masalah}

Pengaturan yang mengatur tentang Lalu Lintas dan Angkutan Jalan diatur di dalam Undang-Undang Nomor 22 Tahun 2009 tentang Lalu Lintas dan Angkutan Jalan. Peraturan ini menjadi dasar hukum untuk memberikan sanksi terhadap pengemudi yang melakukan pelanggaran lalu lintas. Ketentuan mengenai sanksi yang dapat diterapkan terhadap pengemudi yang melakukan pelanggaran dan mengakibatkan kecelakaaan lalu lintas secara jelas telah diatur dalam peraturan tersebut. Dengan adanya keberlakuan peraturan ini, maka kepada masyarakat untuk dapat mematuhi serta mentaati keseluruhan aturan hukum yang telah ditentukan dan mengetahui cara berkendara atau berlalu lintas yang baik dan benar, sehingga akan tecipta kelancaran, keselamatan, rasa aman dalam berlalu lintas. ${ }^{1}$

Peraturan tersebut mengatur tentang tujuan yang ingin dicapai dalam peraturan Lalu Lintas meliputi:

${ }^{1}$ Feriansyach, "Sejarah Singkat Regulasi Lalu Lintas dan Angkutan Jalan diIndonesia", 
1. Terciptanyaa pelayanan berlalu lintas, dapat menciptakan rasa aman, keselamatan, ketertiban, kelancaran, dan keterpaduan untuk meningkatkan perekonomian Nasional, memajukan kesejahteraan umum, memperkukuh persatuan dan kesatuan bangsa, serta dapat menjunjung tinggi martabat bangsa.

2. Terciptanya beretika berlalu lintas sesuai dengan kebudayaan bangsa Indonesia.

3. Terciptanya penegakan hukum dan kepastian hukum bagi masyarakat. ${ }^{2}$

Upaya agar terciptanya keamanan, ketertiban masyarakat dalam berlalu lintas di jalan, aturan hukum berbentuk peraturan perundang-undangan merupakan salah satu alat yang dapat memaksa pemberlakuannya melalui adanya penerapan sanksi terhadap pelanggaran lalu lintas. Permasalahan lalu lintas dan selalu menjadi persoalan utama salah satunya adalah terjadinya kecelakaan lalu lintas. Adapun yang dimaksud dengan kecelakaan lalu lintas pada Pasal 1 butir 24 adalah "terjadinya suatu kejadian di jalan yang melibatkan kendaraan dan dapat menimbulkan korban manusia dan juga kerugian harta benda akibat dari kelalaian pengemudi".

Bentuk kecelakaan lalu lintas menurut aturan hukum yang berlaku terbagi menjadi 3 kategori, yaitu:

1. Kategori Ringan, yaitu kecelakaan lalu lintas yang menimbulkan kerusakan benda atau barang.

2. Kategori sedang, yaitu akibat kecelakaan tersebut dapat menimbulkan luka ringan dan rusaknya kendaraan atau barang.

3. Kategori berat, yaitu akibat kecelakaan tersebut dapat menimbulkan korbannya meninggal dunia atau luka berat. ${ }^{3}$

Untuk penerapan terhadap pelanggaran lalu lintas yang menimbulkan kecelakaan lalu lintas mempunyai sanksi yang berbeda, tergantung dari akibat ditimbulkan dari peristiwa tersebut. Untuk yang masuk kategori ringan, ancaman pidananya adalah diancam dengan pidana penjara paling lama 6 bulan dan atau denda paling banyak Rp. 1.000.000,. Untuk yang masuk kategori sedang diancam dengan pidana penjara paling lama 1 tahun dan atau denda paling banyak Rp. 2.000.000,-. Sedangkan untuk kategori berat yang mengakibatkan korban meninggal dunia diancam dengan pidana penjara paling lama 5 (lima) tahun dan atau denda paling banyak Rp. 10.000.000,-. Maraknya terjadi pelanggaran lalu lintas yang dapat mengakibatkan kecelakaan lalu lintas yang dilakukan oleh anak tentunya menghendaki penyelesaian atau dengan kata lain perlu upaya penegakan hukumnya. Agar jumlah pelanggaran yang dilakukan tidak berkembang dan pelakunya jera untuk mengulangi perbuatannya lagi.

Berdasarkan data yang diperoleh Jumlah pelanggaran yang dilakukan oleh pelajar (anak) yang mengakibatkan kecelakaan lalu lintas dari tahun ke tahun cukup signifikan, Korban jiwa rata-rata 26.000-29.000/tahun (Pendidikan Mayoritas Siswa

${ }^{2}$ Lihat Pasal 3 Undang-Undang Nomor 22 Tahun 2009 Tentang Lalu Lintas dan Angkutan Jalan.

${ }^{3}$ Lihat Pasal Undang-Undang Nomor 22 Tahun 2009 Tentang Lalu Lintas dan Angkutan Jalan. 
SLTA). Pada 2017 jumlahnya mencapai 138.995 kejadian. Pada 2018 hingga Oktober, kecelakaan melibatkan pelajar menengah atas ini sudah mencapai 132.423 kejadian. ${ }^{4}$ Kemudian di kota Jambi, tahun Pada 2017 tercatat sebanyak 6.528 pelanggaran lalu lintas yang dilakukan oleh pelajar. Tahun 2018 sudah tercatat 6.585 pelanggaran lalu lintas. Korban kalangan pelajar pun mencapai 409 orang, dan yang menjadi pelaku kecelakaan 155 orang untuk tahun 2017. Sedangkan Tahun 2018, korban kecelakaan dari kalangan pelajar berjumlah 208 orang. Kemudian pelajar yang menjadi pelaku kecelakaan 124 orang. ${ }^{5}$

Data di atas menunjukkan bahwa anak yang terlibat dalam kecelakaan lalu lintas jumlahnya cukup besar, baik sebagai pelaku yang menyebabkan kecelakaan maupun menjadi korban akibat peristiwa kecelakaan. Apabila terjadi kecelakaan lalu lintas yang dilakukan anak, maka peradilan yang digunakan adalah peradilan yang khusus yaitu peradilan anak, yang berbeda dengan peradilan orang dewasa. Anak diberikan perlindungan khusus walaupun anak sebagai pelaku, tetap mendapatkan hak-haknya sebagaimana ditentukan dalam beberapa peraturan.

Berkaitan dengan penerapan sanksi pidana yang dijatuhkan kepada anak sebagai pelaku kecelakaan lalu lintas menurut Asep Syarifuddin Hidayat menegaskan bahwa "penerapan sanksi pidana yang diterapkan terhadap anak tidak boleh sama pemidanaannya dengan pemidanaan yang dijatuhkan dengan pelaku dewasa." ${ }^{6}$ Hal ini karena adanya perbedaan dilihat dari sifat mental, psikogis serta keinginan anak tidak sama dengan orang dewasa. Demikian pula dengan tingkat pengetahuan hukumnya. Berdasarkan hal tersebut, "maka semesetinya dijadikan dasar untuk menjatuhkan putusan dengan memperhatikan perlindungan hukum anak berdasarkan Undang-Undang Perlindungan Anak."7

Setiap anak wajib diberikan perlindungan, salah satunya adalah dengan menghindarkan akan adanya "stigma" sebagai penjahat pada si anak di masyarakat, dapat menimbulkan pengaruh pada tumbuh kembang anak. Dengan menggunakan pendekatan keadilan restoratif sebagai bentuk perubahan dari penghukuman atau penjatuhan pidana yang berbeda dengan konsep penghukuman yang sudah ada. Yang dimaksud dengan Keadilan restoratif adalah "penyelesaian perkara tindak pidana dengan melibatkan pelaku, korban, keluarga pelaku/korban, dan pihak lain yang terkait untuk bersama-sama mencari penyelesaian yang adil dengan menekankan pemulihan kembali pada keadaan semula, dan bukan pembalasan." 8 Sedangkan yang dimaksud dengan pemidanaan adalah penjatuhan pidana tehadap pelaku dan merupakan upaya hukum terakhir" (ultimum remedium)". Dengan demikian apabila terjadi konflik dalam masyarakat, maka sebaiknya penyelesaian

${ }^{4}$ www.google.com: Koran Sindo terbitan 05 Nopember 2018. Diakses pada tanggal 2 Februari 2020.

${ }^{5}$ Data kasus kecelakaan lalu lintas di Polresta Jambi

${ }^{6}$ Asep Syarifuddin Hidayat, Samul Anam, Muhamad Ishar Helmi, "Perlindungan Hukum Terhadap Anak Sebagai Kurir Narkotika" Jurnal Sosial dan Budaya UIN Syarif Hidayatullah Jakarta,Vol. 5 No. 3 (2018), hlm 4.

${ }^{7}$ Ibid

${ }^{8}$ Lihat Pasal 1 Angka 6 Undang-Undang Nomor 11 Tahun 2012 tentang Sistem Peradilan Pidana Anak. 
yang dilakukan dengan mengutamakan musyawarah dari kedua belah pihak yang bersengketa, dan penyelesaian melalui proses peradilan pidana merupakan upaya hukum terakhir dan penggunaan pidana hendaknya dihindari.

Berkaitan dengan adanya pelanggaran lalu lintas yang mengakibatkan terjadinya kecelakaan lalu lintas yang dilakukan oleh anak, maka solusi terbaik dilakukan adalah dengan Penerapan Diversi. Namun dalam penerapannya sebagai suatu usaha untuk menciptakan Restorative Justice pada perkara kecelakaan lalu lintas yang dilakukan oleh anak tentunya juga bisa memunculkan permasalahan dalam pelaksanaannya. Sulitnya untuk mencapai kata sepakat antara pelaku dan korban, karena pelaku menginginkan adanya ganti rugi yang cukup tinggi. Untuk itu diperlukan pemahaman kepada masyarakat untu dapat mengetahui bagaimana pelaksanaan Diversi pada kecelakaan lalu lintas, bagaimana penerapannya serta apakah ada masalah dalam pelaksanaannya.

\section{Perumusan Masalah}

Berdasarkan apa yang telah dipaparkan, maka yang menjadi pokok persoalan dalam penelitian ini dapat dirumuskan sebagai berikut:

1. Bagaimana pelaksanaan Diversi dalam mewujudkan Restorative Justice pada perkara kecelakaan lalu lintas yang dilakukan oleh anak?

2. Apakah kendala dalam pelaksanaan Diversi?

\section{METODE PENELITIAN}

Tipe penelitian yang dilakukan penulis dengan menggunakan tipe penelitian yuridis normatif. Dalam penelitian hukum normatif, maka yang menjadi kajian adalah:

1. Mendskripsikan hukum positif.

2. Mensistematisasi hukum positif.

3. Menginterprestasikan hukum positif.

4. Menilai hukum positif.

5. Menganalisis hukum positif. ${ }^{9}$

\section{Pendekatan Penelitian}

1. Pendekatan Undang-Undang atau statuta approach dan sebagian ilmuan hukum menyebutnya dengan pendekatan yuridis, yaitu penelitian terhadap aturanaturan hukum. ${ }^{10}$

2. Pendekatan konseptual, yaitu penelitian terhadap teori-teori hukum.

3. Pendekatan kasus atau case approach yaitu dengan melakukan analisis terhadap kasus-kasus yang telah mempunyai kekuatan hukum tetap dan ada kaitannya

\footnotetext{
${ }^{9}$ Bahder Johan Nasution, Metode Penelitian Ilmu Hukum, Mandar Maju, Bandung, 2008, hal. 80.

${ }^{10}$ Ibid., hlm. 92
} 
dengan isu hukum yang dihadapi. ${ }^{11}$ Dalam menggunakan pendekatan kasus, yang perlu dipahami oleh peneliti adalah ratio decendendi, yaitu dasar-dasar hukum yang dipergunakan oleh hakim dalam memutus suatu perkara. ${ }^{12}$

\section{Analisis bahan hukum}

Analisis yang dipergunakan dalam melakukan analisis terhadap bahan hukum dengan cara penafsiran sistematis. "Penafsiran ini dilakukan untuk mendapatkan secara jelas dan konkrit yang terkandung dalam suatu undang-undang dengan cara melakukan pengamatan dan pengkajian terhadap hubungan pasal yang satu dengan pasal yang lain, baik yang terdapt dalam undang-undang itu sendiri maupun yang terkandung dalam undang-undang lain dengan seksama dan cermat," 13

\section{PEMBAHASAN}

Pelaksanaan Diversi dalam mewujudkan Restorative Justice pada perkara kecelakaan lalu lintas yang dilakukan oleh anak.

Penyelesaian perkara anak di Indonesia mempunyai Sistem Peradilan yang tidak sama dengan penyelesaian bukan anak sebagai pelaku tindak pidana. UndangUndang Nomor 11 Tahun 2012 Tentang Sistem Peradilan Pidana Anak mengatur tentang anak yang berkonflik dengan hukum. Yang dimaksud dengan anak berkonflik dengan hukum, penjelasannya ada pada Pasal 1 Angka 3 dirumuskan anak yang berkonflik dengan hukum adalah "Anak yang telah mencapai usia 12 (dua belas) tahun, namun belum mencapai usia 18 (delapan belas) tahun yang diduga melakukan perbuatan pidana." 14

Undang-Undang Nomor 11 Tahun 2012 mengatur mengenai penerapan sanksi pidana dan tindakan yang diberlakukan kepada anak yang perbuatannya merupakan tindak pidana, dan peradilan anak dianggap memberikan kekhususan yaitu dalam hal penangkapan, penyidikan dan tata cara pemeriksaan sidang anak. Sistem pemidanaan terhadap anak yang diatur dalam Sistem Peradilan Pidana Anak dalam penerapan hukumnya bisa menggunakan jalur Diversi. Ketentuan Diversi secara khusus diatur dalam Pasal 6 sampai Pasal 16 Undang-Undang Nomor 11 Tahun 2012 tentang Sistem Peradilan Pidana Anak. Diversi yaitu mengalihkan kasus-kasus pidana yang diduga dilakukan oleh anak dengan penanganan dari metode formal dengan atau tanpa syarat ke proses yang nonformal.

\footnotetext{
${ }^{11}$ Peter Mahmud Marzuki, Penelitian Hukum, Cet. 2, Kencana Prenada Media Group, Jakarta, 2006, hlm. 94

${ }^{12}$ Ibid., hlm. 119

${ }^{13}$ Ibid., hal. 96.

${ }^{14}$ Lihat Pasal 1 Angka 3 Undang-Undang Nomor 11 Tahun 2012 tentang Sistem Peradilan Pidana Anak.
} 
Diversi adalah suatu proses yang dilakukan dengan melibatkan pelaku anak, korban dan masyarakat untuk dapat bersama-sama mencari jalan terbaik dari masalah yang dihadapi, sehingga dapat membuat semuanya menjadi lebih baik dan diperoleh hasil yang dapat memperbaiki, menentramkan dan menciptakan suasana harmonis dan tidak berdasarkan pembalasan. Setiap anak yang melakukan pelanggaran hukum sepantasnya juga diberikan pemenuhan apa yang menjadi haknya, sehingga tidak menimbulkan gangguan psikis dan kejiwaan anak tersebut. Namun selama ini dalam penyelesaiannya dilakukan dengan memposisikan anak sebagai pelaku yang melakukan pelanggaran hukum, lebih banyak penyeselesaiannya melalui proses peradian, sehingga kurang mengedepankan hakhak anak. Untuk itulah diperlukan suatu penyelesaian yang tanpa merugikan hakhak korban dan pelaku.

Namun disatu sisi memberikan ganti rugi yang layak juga kepada korban, artinya ada bentuk perlindungan yang memadai antara pelaku dan korban, apalagi dikhususkan terhadap anak. Pada dasarnya Diversi dilakukan untuk menghindarkan anak dari pengaruh yang kurang baik dalam penerapan sanksi pidana. Terwujudnya penyelesaian perkara anak tanpa melalui proses peradilan karena adanya kata sepakat diantara pelaku anak dan korban, tentunya anak akan terhindar dari perampasan kemerdekaan, mendukung anak untuk turut serta secara aktif dalam kegiatan yang bermanfaat dan menumbuhkan rasa tanggung jawab kepada diri si anak. Diversi juga memiliki maksud untuk tetap menjamin kehidupan dan masa depan anak dengan baik secara fisik maupun psikis.

Untuk kasus yang bisa diselesaikan melalui diversi, maka harus memenuhi aturan yang ada pada Pasal 7 ayat 2 Undang-Undang No. 11 Tahun 2012, yaitu sebagai berikut:

\section{Pasal 7}

(1) Pada tingkat penyidikan, penuntutan, dan pemeriksaan perkara Anak di pengadilan negeri wajib diupayakan Diversi.

(2) Diversi sebagaimana dimaksud pada ayat (1) dilaksanakan dalam hal tindak pidana yang dilakukan: a. diancam dengan pidana penjara di bawah 7 (tujuh) tahun; dan b. bukan merupakan pengulangan tindak pidana.

Dengan ketentuan tersebut berarti apabila melakukan perbuatan yang diancam lebih dari 7 tahun (tujuh) tahun dan perbuatannya sudah berulang, maka boleh tidak dilakukan diversi, hal ini memang dianggap penting mengingat bahwa ancaman hukuman lebih dari 7 (tujuh) tahun tergolong pada tindak pidana berat, sedangkan merupakan pengulangan tindak pidana baik itu sejenis ataupun tidak, maka perkara anak tersebut tidak perlu lagi untuk diselesaikan lewat diversi. Perbuatan yang dilakukan berulang-ulang menjadi pertimbangan untuk tidak dilakukan diversi, karena dapat menumbuhkan komitmen kepada anak untuk tidak mengulangi perbuatannya lagi. 
Proses Diversi yaitu Musyawarah yang dilakukan dengan kehadiran dari Anak dan orang tua/Walinya, korban dan/atau orang tua/Walinya, Pembimbing Kemasyarakatan, dan Pekerja Sosial Profesional berdasarkan pendekatan Keadilan Restoratif. Keadilan Restoratif diselesaikan dengan menghadirkan para pihak yang berperkara untuk bersama-sama menyelesaiakan perkara tersebut untuk dapat memulihkan kembali seperti keadaan semula, yang berarti tidak memperlakukan pelaku sebagai obyek yang harus diberikan hukuman yang sesuai dengan perbuatannya, tetapi diversi juga bertujuan agar kondisi kedua belah pihak yang berperkara dapat dipulihkan ke arah yang lebih baik. "Pertimbangan keharmonisan masyarakat, dengan pemulihan keadaan, maka masyarakat mengganggap adanya keadilan dan kepastian hukum, serta meningkatkan wibawa dan fungsi aparat penegak hukum dalam masyarakat." 15

Walaupun sudah diatur dalam ketentuan untuk pelaksanaan diversi dilakukan secara musyawarah berdasarkan pendekatan Keadilan Restoratif, namun dalam pelaksanaannya kurang memberikan gambaran yang jelas atau tindakan yang harus dilakukan para penegak hukum disetiap proses pemeriksaan dan pihakpihak yang terkait. ${ }^{16}$ Oleh karena itu tetap diperlukan untuk menemukan cara penyelesaian yang dilakukan secara bersama-sama secara adil ke arah yang lebih baik dengan menitikberatkan untuk mengembalikan lagi seperti keadaan sebelumnya, dan bukan merupakan bentuk pembalasan, Sehingga diperlukan adanya suatu tindakan tepat berdasarkan pada Keadilan Restoratif untuk menyelesaiakan pelanggaran hukum yang dilakukan oleh anak.

Termasuk juga memperhatikan kepentingan korban, korban adalah mereka yang dirugikan baik secara penderitaan ataupun fisik, moril dan materril, sehingga hak-hak korban serta pemberian ganti rugi yang layak sesuai kepentingannya. Diversi adalah salah satu kewenangan yang ada pada petugas yang menangani perkara pelanggaran hukum yang dilakukan anak untuk mengambil tindakan apakah melanjutkan kasus atau tidak melanjutkan kasusnya sesuai dengan kebijakan yang dimiliknya. ${ }^{17}$

Berkaitan dengan anak sebagai pelaku kecelakaan lalu lintas baik tang mengakibatkan luka berat atau yang paling parah mengakibatkan matinya orang apakah bias dilakukan upaya diversi, Undang-Undang Nomor 22 Tahun 2009 tentag Lalu Lintas dan Angkutan Jalan mengatur ancaman hukuman kepada pelaku yang mengakibatkan kecelakaan lalu lintas sebagaimana diatur pada Pasal 310 ayat (1) sampai ayat (4) sebagaimana penjelasannya sebagai berikut:

\footnotetext{
${ }^{15}$ Fransiska Novita Eleanora, Penerapan Diversi Terhadap Anak Dalam Sistem Hukum Pidana Indonesia, diakses tgl 25 Juli 2020 .

${ }^{16}$ Wahab Aznul Hidaya, Penerapan Diversi Dalam Sistem Peradilan Pidana Anak, Jurnal Justisi, 2019, hlm. 13

${ }^{17}$ Marlina, Pengantar Konsep Diversi dan Restorative Justice dalam Hukum Pidana, Bandung, Rapika Utama, 2013, hlm. 1
} 
Pasal 310

(1) Setiap orang yang mengemudikan Kendaraan Bermotor yang karena kelalaiannya mengakibatkan Kecelakaan Lalu Lintas dengan kerusakan Kendaraan dan/atau barang sebagaimana dimaksud dalam Pasal 229 ayat (2), dipidana dengan pidana penjara paling lama 6 (enam) bulan dan/atau denda paling banyak Rp1.000.000,00 (satu juta rupiah).

(2) Setiap orang yang mengemudikan Kendaraan Bermotor yang karena kelalaiannya mengakibatkan Kecelakaan Lalu Lintas dengan korban luka ringan dan kerusakan Kendaraan dan/atau barang sebagaimana dimaksud dalam Pasal 229 ayat (3), dipidana dengan pidana penjara paling lama 1 (satu) tahun dan/atau denda paling banyak Rp2.000.000,00 (dua juta rupiah).

(3) Setiap orang yang mengemudikan Kendaraan Bermotor yang karena kelalaiannya mengakibatkan Kecelakaan Lalu Lintas dengan korban luka berat sebagaimana dimaksud dalam Pasal 229 ayat (4), dipidana dengan pidana penjara paling lama 5 (lima) tahun dan/atau denda paling banyak Rp10.000.000,00 (sepuluh juta rupiah).

(4) Dalam hal kecelakaan sebagaimana dimaksud pada ayat (3) yang mengakibatkan orang lain meninggal dunia, dipidana dengan pidana penjara paling lama 6 (enam) tahun dan/atau denda paling banyak Rp12.000.000,00 (dua belas juta rupiah). ${ }^{18}$

Jika dilihat dari ketentuan Pasal diatas yang mengatur mengenai sanksi terhadap kecelakaan lalu lintas karna kelalaiannya, sanksi maksimal yang diterapkan yaitu 6 (enam) tahun penjara yaitu yang mengakibatkan matinya orang sebagaimana diatur pada Pasal 310 Ayat (4). Maka jika dilihat dari ancaman hukumannya makan anak sebagai pelaku kecelakaan lalu lintas bias diupayakan diversi, dan wajib diupayakan dimulai dari proses Penyidikan sampai Pengadilan.

Penyelesaian kasus melalui diversi harus berpedoman pada Peraturan Pemerintah Nomor 65 Tahun 2015 tentang Pedoman Pelaksanaan Diversi dan Penanganan Anak yang Belum mencapai umur 12 (Dua Belas) tahun, juga adanya penjelasan tentang:

1. Kepentingan Korban adalah korban punya hak untuk diperhatikan secara proporsional.

2. Hak-hak anak berupa kesejahteraan tetap harus diberikan, namun anak juga tetap harus bertanggungjawab atas kesalahan yang dilakukannya dan mentaati kesepakatan diversi dengan melakukan pembinaan.

Berdasarkan hal tersebut, maka untuk kasus yang dapat diselesaikan melalui diversi yang dilakukan oleh penyidik, penuntut umum, dan hakim dengan mempertimbangkan 4 (empat) hal yaitu:

${ }^{18}$ Lihat Pasal 310 Undang-Undang Nomor 22 Tahun 2009 tentang Lalu Lintas dan Angkutan Jalan. 
1. Ketentuan klasipikasi tindak pidana yang dilakukan yaitu ketentuan yang merupakan parameter dari ancaman pidananya, apabila ancaman pidananya rendah, maka tingkat keberhasilan diversinya cukup besar dan sebaliknya.

2. Usia anak, merupakan salah satu prioritas untuk diberikan diversi, anak yang usianya muda, lebih diutamakan untuk mendapatkan diversi.

3. Mendapatkan rekomendasi dari Bapas untuk diversi berdasarka hasil penelitian yang telah dilakukan Bapas.

4. Mendapatkan dukungan yang diberikan oleh lingkungan keluarganya dan masyarakat.

Walaupun syarat-syaratnya sudah terpenuhi, tapi tetap yang utama adalah memperoleh persetujuan dari korban dan keluarganya serta kesanggupan anak dan keluarganya. Yang berarti walaupun syarat-syaratnya terpenuhi belum tentu diversi terlaksana. Dalam penerapannya, sebagai suatu usaha untuk menciptakan Restorative Justice pada perkara kecelakaan lalu lintas yang dilakukan oleh anak tentunya juga bisa memunculkan permasalahan dalam pelaksanaannya. UndangUndang sistem peradilan pidana anak memberikan kesempatan kepada pelaku, maupun korban dan saksi untuk menyelesaikan perkara secara perdamaian sepanjang adanya kata sepakat diantara mereka. Kata sepakat yang timbul tersebutlah yang kemudian menjadi dasar untuk diterapkannya diversi.

\section{Kendala Dalam Pelaksanaan Diversi}

Tujuan yang ingin dicapai dalam proses diversi adalah terwujudnya keadilan restorative atau Restorative Justice, terhadap anak sebagai pelaku maupun bagi korban sebagaimana dirumuskan dalam Pasal 8 ayat (1) Sistem Peradilan Pidana Anak. "Musyawarah yang dilakukan dengan melibatkan pihak yang terlibat, yatu anak dari orang tua/walinya, korban dan/atau orang tua/walinya, pembimbing kemasyarakatan, dan pekerja sosial profesional berdasarkan pendekatan keadilan restoratif." Dalam penerapannya, sebagai suatu usaha untuk menciptakan Restorative Justice pada perkara kecelakaan lalu lintas yang dilakukan oleh anak tentunya juga bisa memunculkan permasalahan dalam pelaksanaannya, Sulitnya untuk mencapai kata sepakat antara pelaku dan korban, karena pelaku menginginkan adanya ganti rugi yang cukup tinggi.

Keadilan restoratif merupakan suatu proses diversi, baik pelaku, korban, Pembimbing kemasyarakatan dan pihak yang terlibat dalam kasus kecelakaan lalu lintas bersama-sama mencari solusi untuk menemukan jalan terbaik guna terciptanya suatu keadaan yang dapat memperbaiki, dan menenteramkan hati dan tidak berdasarkan pembalasan. Konsep Diversi merupakan hal baru dalam penegakan hukum, sehingga dalam pelaksanaannya menemukan beberapa kendala, diantaranya:

\section{Masih kurangnya Pemahaman Masyarakat Mengenai Diversi}


Stigma Masyarakat yang masih beranggapan bahwa apabila seseorang melakukan perbuatan yang melanggar hukum, maka pelakunya harus diproses melalui jalur hukum pula dan pelakunya harus masuk penjara, demikian pula apabila pelakunya anak, masyarakat tetap menginginkan kasusnya diselesaikan melalui jalur hukum, termasuk kasus kecelakaan lalu lintas, masyarakat meminta untuk diselesaikan melalui jalur peradilan, karena masyarakat menganggap apabila pelakunya masuk penjara akan dapat memberikan efek jera pelakunya. Termasuk kasus yang berkaitan dengan kecelakaan lalu lintas yang karna kelalaian anak mengakibatkan orang lain meninggal dunia, hal ini masih ada stigma yang mengatakan bahwa anak sebagai pembunuh, sehingga ini bias menambah bebas psikis pada anak.

Berkaitan dengan hal tersebut, tentunya proses diversi tidak akan berjalan dengan baik dan merupakan penghalang dalam pelaksanaan diversi. Masyarakat masih banyak yang belum mengetahui proses diversi digunakan untuk menyelesaikan kasus anak yang berkonflik dengan hukum sebagaimana tujuan dari Diversi yang diatur pada Pasal 6 Undang - Undang Nomor 11 Tahun 2012 tentang Sistem Peradilan Pidana Anak sebagai berikut:

Pasal 6

Diversi bertujuan:

a. mencapai perdamaian antara korban dan Anak;

b. menyelesaikan perkara Anak di luar proses peradilan;

c. menghindarkan Anak dari perampasan kemerdekaan;

d. mendorong masyarakat untuk berpartisipasi; dan

e. menanamkan rasa tanggung jawab kepada Anak. ${ }^{19}$

Penyelesaian perkara lalu lintas yang dilakukan anak dengan Sistem diversi yang merupakan alternatif dalam penyelesaian kasus anak yang berkonflik dengan hukum belum banyak diketahui masyarakat, sehingga memang harus dilakukan sosialiasi oleh Aparat penegak hukum dan pihak terkait kepada masyarakat, karena faktanya yang terjadi di masyarakat menganggap hanya dengan penyelesaian perkara pidana anak dengan menggunakan proses pradilan atau melalui jalur hukum yang dapat memberikan efek jera kepada pelaku. Oleh karena itu memang diperlukan sosialisasi kepada masyarakat terkait proses diversi dalam menyelesaikan kasus pelanggaran lalu lintas yang pelakunya anak.

\section{Tidak tercapainya kata sepakat ganti rugi}

Proses diversi melalui musyawarah antara pelaku dan pihak korban adakalanya tidak mendapatkatkan kata sepakat. Undang-Undang sistem peradilan pidana anak memberikan kesempatan kepada pelaku, maupun korban dan saksi untuk

\footnotetext{
${ }^{19}$ Lihat Pasal 6 Undang-Undang Nomor 11 Tahun 2012 tentang Sistem Peradilan Pidana Anak
} 
menyelesaikan perkara secara perdamaian sepanjang adanya kata sepakat diantara mereka. Kata sepakat yang timbul tersebutlah yang kemudian menjadi dasar untuk diterapkannya diversi.

Tidak adanya kata sepaka tersebut terjadi karena besarnya tuntutan ganti yang diminta oleh pihak korban, sementara pihak pelaku tidak mampu memenuhi permintaan yang diajukan oleh korban. Beberapa kasus kecelakaan lalu lintas, diversi tidak dapat terwujud, karena tidak tercapainya kata sepakat akan jumlah ganti rugi yang diminta oleh korban. Besarnya tuntutan ganti rugi yang diminta oleh pihak korban sehingga pihak pelaku tidak mampu memenuhi permintaan yang diajukan oleh korban, dikarnakan Undang-Undang Nomor 11 Tahun 2012 tentang Sistem Peradilan Pidana Anak belum mengatur secara jelas mengenai ganti kerugian melalui upaya Diversi.

\section{Kesimpulan}

\section{KESIMPULAN DAN SARAN}

1. Sistem Peradilan Pidana Anak mewajibkan untuk melakukan upaya Diversi antara pelaku dan korban demi kepentingan tumbuh kembang anak dan masa depan anak, tidak semua kasus kecelakaan lalu lintas yang melibatkan anak dapat diselesaikan melalui Diversi, karena Diversi dapat terwujud apabila telah memenuhi syarat yang telah ditentukan dalam peraturan yang berlaku dan adanya kata sepakat antara pelaku dan korban untuk Diversi.

2. Tidak diaturnya secara jelas mengenai ganti kerugian antara pelaku dan korban yang melakukan upaya Diversi dalam Undang-Undang Nomor 11 Tahun 2012 tentang Sistem Peradilan Pidana Anak menjadi kendala/hambatan penting dalam proses pelaksanaan Diversi tersebut.

\section{Saran}

1. Proaktif melakukan penyuluhan hukum oleh aparat maupun stackholder terkait untuk meningkatkan kesadaran tentang pentingnya mengupayakan Diversi karena dapat menghindarkan anak dalam proses Peradilan pidana sebagaimana yang diamanatkan dalam Undang-Undang Nomor 11 Tahun 2012 tentang Sistem Peradilan Pidana Anak.

2. Pemberian Surat Ijin Mengemudi atau SIM harusnya diperketat, dan terdapat kontrol atau evaluasi terhadap SIM yang sudah diterbitkan.

3. Perlunya diatur secara jelas mengenai ganti kerugian dalam hal upaya Diversi guna adanya kata sepakat bagi kedua belah pihak dalam UU SPPA melalui pembaharuan hukum atau produk hukum yang baru (Peraturan Pemerintah). 


\section{DAFTAR PUSTAKA}

\section{Buku}

Abdussalam, Hukum Perlindungan Anak, Restu Agung, Jakarta, 2007.

Adi, Kusno. Diversi Sebagai Upaya Alternatif Penanggulangan Tindak Pidana Narkotika Oleh Anak, Malang: UMM Press, 2009.

Abintoro Prakoso, Pembaruan Sistem Peradilan Pidana Anak, Laksbang Grafika, Yogyakarta, 2013.

Bahder Johan Nasution, Metode Penelitian Ilmu Hukum, Mandar Maju, Bandung, 2008. Maidin Gultom, Perlindungan Hukum Terhadap Anak, Refika Aditama, Bandung, 2008. Koesno Adi, Diversi Tindak Pidana Narkotika Anak, Setara Pess, Semarang, 2014.

\section{Jurnal Ilmiah}

Asep Syarifuddin Hidayat, Samul Anam, Muhamad Ishar Helmi, Perlindungan Hukum Terhadap Anak Sebagai Kurir Narkotika, Jurnal Sosial dan Budaya UIN Syarif Hidayatullah Jakarta Vol. 5 No. 3 (2018).

Dina Novitasari, Jurnal Hukum Khaira Ummah, Vol. 12, Tahun 2017.

Heny Harsono dalam artikel Vinda Fitria Ananda, Eko Raharjo, Rini Fathonah, Perlindungan Hukum Terhadap Anak Sebagai Pelaku Tindak Pidana Penyalahgunaan Narkotika, Fakultas Hukum UNILA, 2018.

Harkristuti Harkrisnowo, Tantangan dan Agenda Hak-Hak Anak, Newsletter Komisi Hukum Nasional, Edisi Februari 2002, Jakarta.

Hafrida, Yulia Monita, dan Elizabeth Siregar. "Pembinaan Narapidana Ana Di Lembaga Pemasyaraktan Anak Sei. Bulu Muara Bulian,"(Hasil peneilitan). Jurnal Publikasi Pendidikan, Vol 5 No. 3, 2015.

Lilik Purwastuti, Sri Rahayu, Reformasi Perlindungan Hukum Terhadap anak Sebagai Pelaku Tindak Pidana Dalam Peradilan Pidana Indonesia, Inovatif Jurnal Ilmu Hukum, 2013.

Ibrahim Fikma Edrisy, Implementasi rehabilitasi Terhadap Anak Penyalahguna Narkotika, Fiat Justisia Journal Of Law, Volume 10, Tahun 2016.

Merry Natalia Sinaga, Ide Dasar Double Track System: Sanksi Pidana dan Tindakan Sebagai Sistem Pemidanaan Terhadap Pelaku Kejahatan Penyalahgunaan Narkotika, Jurnal Penelitian Pendidikan Sosial Humaniora, Vol.3 No.1 Tahun 2018.

Sony Kusuma, Anak Berhadapan dengan Hukum, Hukum Online.com, Minggu, 09 Februari 2020.

\section{Peraturan Perundang-Undangan}

Undang-Undang Nomor 22 Tahun 2009 tentang Lalu Lintas dan Angkutan Jalan Undang-Undang Nomor 11 Tahun 2012 tetntang Sistem Peradilan Pidana Anak Undang-Undang Nomor 35 Tahun 2014 tentang Perlindungan Anak

Peraturan Pemerintah Nomor 65 Tahun 2015 tentang Pedoman Pelaksanaan Diversi dan Penanganan Anak yang Belum mencapai umur 12 (Dua Belas) tahun 